\title{
Influence of passive immunization against GnRH on pregnancy and parturition in the tammar wallaby, Macropus eugenii
}

\author{
R. V. Short, A. P. F. Flint* and M. B. Renfree \\ Departments of Anatomy \& Physiology, Monash University, Clayton, Victoria 3168, Australia and \\ *A.F.R.C. Institute of Animal Physiology, Babraham, Cambridge, CB2 4AT, U.K.
}

\begin{abstract}
Summary. Pouch young were removed from 10 wallabies in lactational diapause, and half the animals were injected intravenously with $8 \mathrm{ml}$ normal wallaby serum or $8 \mathrm{ml}$ GnRH antiserum every 3rd day from the day of removal of pouch young until Day 30. Laparotomies were performed on Day 24 to monitor luteal size, follicular development and uterine enlargement. The pouches were examined daily for the presence of newborn young from Days 26 to 30, and all the animals were killed on Day 30.

The corpora lutea had hypertrophied in all the animals of both groups by Day 24, but none of the antiserum-treated animals showed any signs of follicular development (follicles $<1 \mathrm{~mm}$ diam.), whereas all the control animals had large follicles (mean $3.5 \mathrm{~mm}$ diam.). In each group $4 / 5$ animals were visibly pregnant at laparotomy, and parturition occurred normally in 3 of the experimental animals and 1 of the controls.

At autopsy, none of the antiserum-treated animals showed any evidence of follicular development or post-partum ovulation, whereas 3 of the controls had new corpora lutea and the other 2 had large preovulatory follicles. These differences were reflected in the weights of the lateral vaginae; the treated animals showed no evidence of oestrogenic stimulation $(4.9 \pm 0.2 \mathrm{~g})$, whereas the controls showed the hypertrophy characteristic of oestrus $(9 \cdot 5 \pm 1 \cdot 2 \mathrm{~g})$. Lactogenesis, as measured by an increase in mammary gland lactose concentrations, was established in all animals, regardless of treatment.

These results indicate that passive immunization with a $\mathrm{GnRH}$ antiserum reduced pituitary FSH and LH secretion, thereby inhibiting follicular development during pregnancy and preventing post-partum oestrus and ovulation. Since parturition occurred normally in 3 of the 4 pregnant treated animals, follicular development in late gestation cannot be important in the initiation of labour, nor is it required for normal lactogenesis. Passive immunization failed to prevent hypertrophy of the corpus luteum after removal of the pouch young, confirming that neither FSH nor LH are likely to be involved in this process.
\end{abstract}

\section{Introduction}

The tammar wallaby, like the majority of macropodid marsupials, has a gestation length in the absence of embryonic diapause that is shorter than the length of its oestrous cycle, so that it normally comes into oestrus within a day of giving birth (Tyndale-Biscoe, 1984). It appears that the rising oestrogen secretion at parturition is follicular in origin (Shaw \& Renfree, 1984; Harder, Hinds, Horn \& Tyndale-Biscoe, 1984), but is unlikely to be the trigger for the onset of parturition since births occur normally in animals without a developing follicle in late pregnancy (Tyndale-Biscoe, Hearn \& Renfree, 1974; Harder, Hinds, Horn \& Tyndale-Biscoe, 1985). 
If wallabies are hypophysectomized during embryonic diapause, there is luteal hypertrophy, blastocyst reactivation and a normal pregnancy, but parturition fails to occur and follicles fail to develop (Hearn, 1974). Likewise, if the corpus luteum of pregnancy is removed (Young \& Renfree, 1979), or if bilateral ovariectomy is performed in late gestation (Harder et al., 1985), parturition fails to occur. These results suggest that the corpus luteum, once formed, requires no further pituitary gonadotrophic support for its maintenance, that the luteal hypertrophy that occurs after hypophysectomy must be due to the removal of some pituitary 'gonadostatin', and that the presence of a fully functional corpus luteum may be necessary for the initiation of parturition.

The endocrinology of pregnancy and parturition in the tammar wallaby is therefore quite unlike that of any eutherian mammal hitherto described. To obtain further evidence about the precise roles of follicle-stimulating hormone (FSH) and luteinizing hormone (LH) in the regulation of follicular and luteal activity during pregnancy, parturition, and in the immediate post-partum period, we have passively immunized wallabies against gonadotrophin-releasing hormone (GnRH), a procedure that is known to be effective in eutherian mammals for the selective inhibition of gonadotrophin secretion (Fraser, 1981).

\section{Materials and Methods}

Animals. Tammar wallabies were obtained from the wild on Kangaroo Island, South Australia, and maintained in a captive breeding colony as previously described (Renfree, Green \& Young, 1979). The animals were kept in open grassed enclosures, and lucerne hay, oats and water were freely available. Two mature intact males, two ovariectomized females and two mature intact females without pouch young were actively immunized against a $\mathrm{GnRH}$ conjugate to produce a pool of antiserum, and 10 animals with sucking pouch young and presumed to be carrying blastocysts in lactational diapause were used for passive immunization.

Preparation of the antigen. Synthetic GnRH (Hoechst, A.G., Frankfurt, W. Germany), 6 mg, and $6 \mathrm{mg}$ human serum albumin were dissolved in $0.75 \mathrm{ml}$ distilled water. To this was added $150 \mathrm{mg}$ 1-ethyl-3-(dimethylamino-propyl)carbodiimide HC1 (Sigma, St Louis, MO, U.S.A.) dissolved in $250 \mu$ l water. After mixing, the solution was allowed to stand at room temperature overnight in the dark. It was then dialysed in Visking tubing against distilled water at $4^{\circ} \mathrm{C}$ for 2 days. The dialysate was then made up to $9 \mathrm{ml}$ with sterile $0.9 \%(\mathrm{w} / \mathrm{v}) \mathrm{NaCl}$ and emulsified in $12 \mathrm{ml}$ Freund's complete adjuvant (Difco, Clayton, Victoria 3168, Australia), and used for active immunization.

Active immunization. The 6 animals were each given 5-7 subcutaneous injections of $0.5 \mathrm{ml}$ antigen on 9 June 1980. No booster injections were given, and the animals were killed and exsanguinated on 3 December 1980. Antibody titres at this time were measured as the maximum serum dilution to allow binding of $33 \%$ of added ${ }^{125} \mathrm{I}$-labelled $\mathrm{GnRH}$, and these are shown in Table 1 . The serum from Tammar 390 was subsequently discarded in view of its low antibody titre,

Table 1. Volume of serum and GnRH antibody titre obtained 6 months after active immunization of wallabies against a GnRH-human serum albumin conjugate

\begin{tabular}{cccc}
\hline Animal no. & Sex & $\begin{array}{c}\text { Serum vol. } \\
(\mathrm{ml})\end{array}$ & Antibody titre* \\
\hline 74 & 0 & 78 & $1: 4800$ \\
181 & 0 & 54 & $1: 6400$ \\
272 & $\$$ & 58 & $1: 20000$ \\
390 & $\$$ & 86 & $1: 1400$ \\
428 & $\$$ & 56 & $1: 10000$ \\
430 & + & 36 & $1: 8000$ \\
\hline
\end{tabular}

* Titres are expressed as the maximal dilution of serum that gave binding of $33 \%$ of added ${ }^{125}$ I-labelled GnRH. 

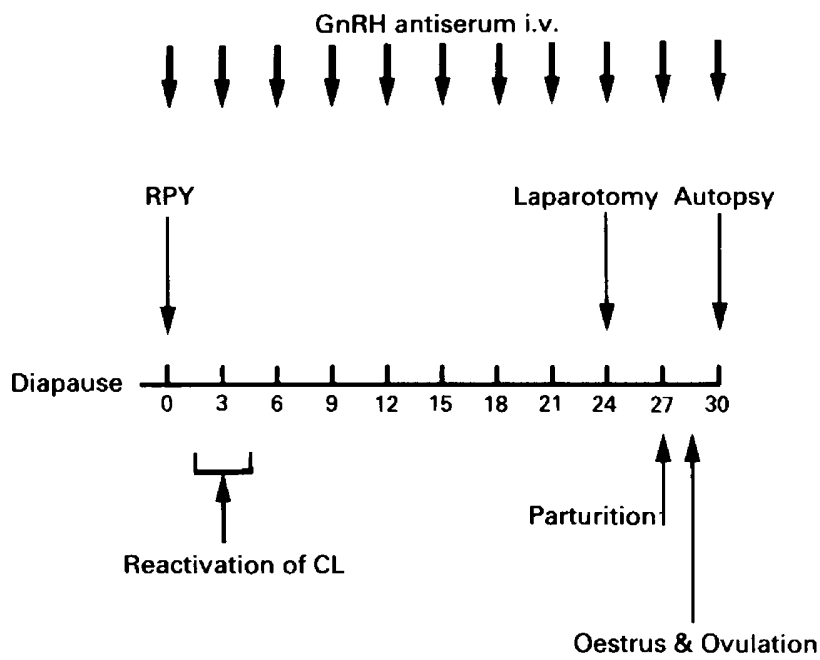

Text-fig. 1. Experimental protocol, showing days of each treatment (above line) in relationship to day of removal of pouch young (RPY) on Day 0, and indicating the normal sequence of events (below line).

and the other sera were pooled, sterilized by passage through a millipore filter and deep-frozen in $8 \mathrm{ml}$ aliquants for passive immunization; the antibody titre of this pool was 1:12 000. Some indication of the success of the active immunization procedure in inhibiting endogenous GnRH and hence FSH and LH secretion was obtained by examining the combined testicular weights of the two males; these were $22.5 \mathrm{~g}$ for Tammar 74 and $15.1 \mathrm{~g}$ for Tammar 181 . The animal with the higher antibody titres had the smaller testes; these values should be compared with normal mean \pm s.d. testicular weights for tammars of $29.9 \pm 6.5 \mathrm{~g}$ (Tyndale-Biscoe \& Renfree, 1986).

Passive immunization. Pouch young were removed from 10 wallabies on 10 February 1981 . The animals were allocated equally to control and treatment groups, and, beginning from the day of removal of pouch young (Day 0), and every 3 days thereafter until Day 30, the animals were given intravenous injections via the tail vein of $8 \mathrm{ml}$ normal wallaby serum or $8 \mathrm{ml} \mathrm{GnRH}$ antiserum. The experimental protocol is summarized in Text-fig. 1. Plasma samples collected on Days 3, 6 and 9 from 3 of the antiserum-treated animals were assayed for their GnRH antibody titres, and the results are shown in Table 2.

Table 2. GnRH antibody titres in 3 wallabies after repeated passive immunization with $8 \mathrm{ml}$ aliquants of GnRH antiserum

\begin{tabular}{cccc}
\hline & \multicolumn{3}{c}{ Antibody titre* } \\
\cline { 2 - 4 } Animal no. & First & Second & Third \\
\hline 1008 & $1: 340$ & $1: 550$ & $1: 720$ \\
1026 & $1: 290$ & $1: 650$ & $1: 680$ \\
1231 & $1: 340$ & $1: 650$ & $1: 850$ \\
\hline
\end{tabular}

* Titres are expressed as the dilution of serum required to bind $33 \%$ of added ${ }^{125}$ I-labelled GnRH 3 days after the first, second and third injections of antiserum. 
Blood sampling. Blood samples $(10 \mathrm{ml})$ were collected into heparinized syringes from all the animals immediately before each antiserum administration, and daily from Days 27 to 30 ; the plasma was separated by centrifugation and stored at $-20^{\circ} \mathrm{C}$ for subsequent steroid assay.

Laparotomy. On Day 24, all the animals were laparotomized. Anaesthesia was induced with intravenous pentobarbitone sodium (Abbott, Kurnell, N.S.W., Australia) administered via a tail vein, and maintained with halothane (Fluothane, I.C.I. Villawood, N.S.W. 2163, Australia) and oxygen. The abdomen was opened by a mid-line ventral incision through the skin of the pouch and the uteri and ovaries were exposed. The diameters of the follicles and corpora lutea were measured with a micrometer, and the sizes of the uteri were recorded. The incision was dusted with antibiotic powder (Tricin: V.R. Laboratories, Thornleigh, N.S.W., Australia) and sutured. Each animal was given a prophylactic injection of $1 \mathrm{ml}$ antibiotic (Duplocillin: V.R. Laboratories), and they all made uneventful recoveries.

Timing of birth. Starting on Day 27, the pouches were examined daily for the presence of newborn young, and the urogenital sinuses for the presence of copulatory plugs.

Autopsy. On Day 30, the animals were killed with an overdose of intravenous pentobarbitone sodium. The reproductive tracts were dissected out and photographed, and the ovaries were examined for the presence of follicles and recent ovulations. The ovaries were then fixed in neutral buffered formalin, serially sectioned and stained with haematoxylin and eosin for subsequent histological examination. The uteri were examined for the presence of fetuses or evidence of recent pregnancy. The lateral vaginae were dissected free of adjacent connective tissue, weighed to provide an index of the animal's oestrogenic status, and then fixed in formalin, sectioned, and stained with haematoxylin and eosin. A piece of mammary gland was frozen for subsequent lactose determinations, according to the procedure of Findlay, Ward \& Renfree (1983).

Steroid assays. Progesterone was determined by a radioimmunoassay validated for tammars by Ward \& Renfree (1984) using progesterone antiserum S230 provided by Dr R. I. Cox, CSIRO Hormone Assay Group, Sydney. The assay sensitivity was $9 \mathrm{pg} / \mathrm{ml}$ and the intra- and interassay coefficients of variation were $8 \%$ and $15 \%$ respectively. Oestradiol-17 $\beta$ concentrations were measured according to Flint \& Renfree (1982) using antiserum (dilution 1:20 000) raised against oestradiol conjugated to bovine serum albumin at the 6-position, provided by Dr B. J. A. Furr, ICI Pharmaceuticals Division, Macclesfield, Cheshire, U.K. The assay sensitivity was $2.5 \mathrm{pg} / \mathrm{ml}$ and the intra- and interassay coefficients of variation were $11 \%$ and $10.7 \%$ respectively.

\section{Results}

\section{Findings at laparotomy}

When the animals were examined at laparotomy on Day 24, it was apparent that 4 of the 5 animals in each group were pregnant, as judged by the enlargement of one uterus. On inspecting the ovaries, an hypertrophied functional corpus luteum $4.2-5.0 \mathrm{~mm}$ in diameter was present in all the animals, and this was always in the ovary adjacent to the uterus carrying the fetus (see Table 3 ). A large preovulatory follicle of $3.3-3.7 \mathrm{~mm}$ diameter was present in the contralateral ovary of all the pregnant controls, but no large follicles were detected in any of the GnRH-immunized animals. Immunization had not therefore prevented the hypertrophy of the corpus luteum after removal of the pouch young and it had not prevented blastocyst reactivation, but it had prevented normal follicular development during pregnancy. 
Table 3. Diameter of corpus luteum and largest follicle at laparotomy on Day 24 and at autopsy on Day 30 in control and GnRH-immunized wallabies

\begin{tabular}{|c|c|c|c|}
\hline \multirow[b]{2}{*}{$\begin{array}{l}\text { Treatment and } \\
\text { animal no. }\end{array}$} & \multicolumn{2}{|c|}{ Day 24} & \multirow{2}{*}{$\frac{\text { Day } 30}{\begin{array}{c}\text { Structures present in } \\
\text { ovaries and side }\end{array}}$} \\
\hline & $\begin{array}{l}\text { Diam. of CL (mm) } \\
\text { and side }\end{array}$ & $\begin{array}{l}\text { Diam. of follicle (mm) } \\
\text { and side }\end{array}$ & \\
\hline $\begin{array}{l}\text { CONTROL } \\
1011\end{array}$ & $4 \cdot 2, \mathrm{R}$ & $3 \cdot 7, \mathrm{~L}$ & Recent ovulation $\mathrm{L}$, old CL R \\
\hline 1025 & $5 \cdot 0, \mathrm{R}$ & $3 \cdot 3, \mathrm{~L}$ & Recent ovulation $\mathrm{L}$, old CL R \\
\hline 1173 & $4 \cdot 6, \mathrm{R}$ & $3 \cdot 3, \mathrm{~L}$ & $\begin{array}{l}4.3 \mathrm{~mm} \text { follicle } L, \text { old } C L R \text {, copulatory } \\
\text { plug in vagina }\end{array}$ \\
\hline 1352 & $4 \cdot 4, \mathrm{R}$ & $3 \cdot 7, \mathrm{~L}$ & $3.6 \& 3.5 \mathrm{~mm}$ follicles $\mathrm{L}$, old CL $R$ \\
\hline $1357^{*}$ & $4 \cdot 4, \mathrm{~L}$ & N.D. & Recent ovulation $R$, old CL L \\
\hline $\begin{array}{l}\text { GNRH ANTISERUM } \\
1008\end{array}$ & $4 \cdot 9, \mathrm{R}$ & N.D. & $\begin{array}{l}\text { No large follicles or recent ovulation, old } \\
\text { CL } R\end{array}$ \\
\hline 1026 & $4 \cdot 4, R$ & N.D. & $\begin{array}{l}\text { No large follicles or recent ovulation, old } \\
\text { CL } R\end{array}$ \\
\hline $1172^{*}$ & $4 \cdot 2, \mathrm{~L}$ & N.D. & $\begin{array}{l}\text { No large follicles or recent ovulation, old } \\
\text { CL L }\end{array}$ \\
\hline 1186 & $4 \cdot 4, \mathrm{R}$ & N.D. & $\begin{array}{l}\text { No large follicles or recent ovulation, old } \\
\text { CL } R\end{array}$ \\
\hline 1231 & $4 \cdot 7, \mathrm{~L}$ & N.D. & $\begin{array}{l}\text { No large follicles or recent ovulation, old } \\
\text { CL L }\end{array}$ \\
\hline
\end{tabular}

N.D. = not detectable, $<1 \mathrm{~mm}$.

* Not pregnant.

\section{Timing of birth}

One control animal gave birth on Day 27 (No. 1025) and 3 of the treated animals gave birth on Days 28 (No. 1231), 29 (No. 1008) and 30 (No. 1186). The failure to find newborn pouch young in the remaining 3 controls and one treated animal, and the fact that their uteri were empty at autopsy on Day 30, indicates either that they aborted after the laparotomy on Day 24, which occurs in about $25 \%$ of animals operated at this stage of gestation (Young \& Renfree, 1979), or that parturition occurred at the normal time, but that the young failed to enter the pouch successfully, which is not an uncommon finding when animals are being caught daily at around the expected time of parturition.

\section{Findings at autopsy}

At autopsy on Day 30, 3 of the control animals had recent ovulations and the other 2 had large preovulatory follicles (see Table 3); one of these two (No. 1173) also had a copulatory plug in the urogenital sinus, confirming that it had already come into oestrus. The fact that the preovulatory follicles or new ovulations were always in the ovary contralateral to the regressing corpus luteum of the previous cycle confirms the fact that, in the tammar, ovulations normally alternate between the two ovaries.

In contrast to the controls, none of the GnRH-immunized animals showed any signs of preovulatory follicles or recent ovulations in either ovary (see Table 3). These differences in ovarian activity between the two groups were reflected elsewhere in the reproductive tract; on gross inspection there was a major difference in the size of the median and lateral vaginae (Pl. 1, Fig. 1). This 
Table 4. Weights of lateral vaginae and mammary gland lactose concentrations in the non-sucked gland at autopsy on Day 30 in control and GnRH-immunized wallabies

\begin{tabular}{lccc}
\hline Treatment & Animal no. & Vaginal wt $(\mathrm{g})$ & Lactose $(\mu \mathrm{g} / \mathrm{g}$ tissue) \\
\hline Control & 1011 & $11 \cdot 81$ & 195 \\
& 1025 & $8 \cdot 80$ & $251^{*}$ \\
& 1173 & $13 \cdot 08$ & 865 \\
& 1352 & $7 \cdot 95$ & 436 \\
& 1357 & $5 \cdot 84$ & $397 \pm 62$ \\
\cline { 2 - 4 } & Mean \pm s.e.m. & $9 \cdot 50 \pm 1 \cdot 17$ & $1890^{*}$ \\
\hline GnRH antiserum & 1008 & $4 \cdot 22$ & 1046 \\
& 1026 & $5 \cdot 08$ & 1652 \\
& 1172 & $5 \cdot 50$ & $687^{*}$ \\
& 1186 & $6 \cdot 58$ & $1290 \pm 108$ \\
\hline Sucking pouch young present on another teat at the time of autopsy. Normal lactose values up \\
to Day 25 of pregnancy are $115 \pm 24 \mu \mathrm{g} / \mathrm{g}$ (Findlay et al., 1983).
\end{tabular}

was reflected in their weights, which were significantly different $(P=0.005)$ (see Table 4$)$, and their histological appearance, with the controls clearly having a thicker layer of stratified squamous epithelium than the treated animals ( Pl. 1, Figs 2 \& 3). Histological examination of the ovaries themselves confirmed the gross morphological observations; the immunized animals showed a normal regressing corpus luteum and a few small primordial follicles, whereas the controls had a well-developed preovulatory follicle or a recently formed corpus luteum in addition to a normal regressing corpus luteum (Pl. 2, Figs 4-7). Therefore the antiserum administration had not apparently influenced the timing of birth, although it had completely suppressed the follicular development and oestrogen secretion that normally precede post-partum oestrus and ovulation.

Measurement of the lactose concentrations in mammary tissue showed the expected postpartum rise in both groups, although this was greater in the immunized animals than in the controls (see Table 4).

\section{Steroid assays}

The results of the progesterone determinations are shown in Text-fig. 2. Animals in both groups showed rising concentrations throughout the course of the experiment, with an abrupt fall at the

\section{PLATE 1}

Fig. 1. Ventral view of the reproductive tracts of a GnRH-immunized animal, No. 1008 (a), and a control, No. 1025 (b), at autopsy on Day 30, showing the enlargement of the lateral vaginae of the control, which had just ovulated and so had a new corpus luteum (NCL). Both animals had recently given birth from the right uterus, which is still slightly enlarged, and each had a regressing corpus luteum in the ipsilateral ovary. BL, bladder; $L V$, lateral vagina; $M V$, median vagina; PU, parturient uterus; UGS, urogenital sinus; Ur, ureter. $\times 0 \cdot 7$.

Fig. 2. Histological appearance of the lateral vagina of a GnRH-immunized animal, No. 1186, showing unstimulated epithelium. $\times 250$.

Fig. 3. Histological appearance of the lateral vagina of a control animal, No. 1173, showing hypertrophied epithelium. $\times 250$. 

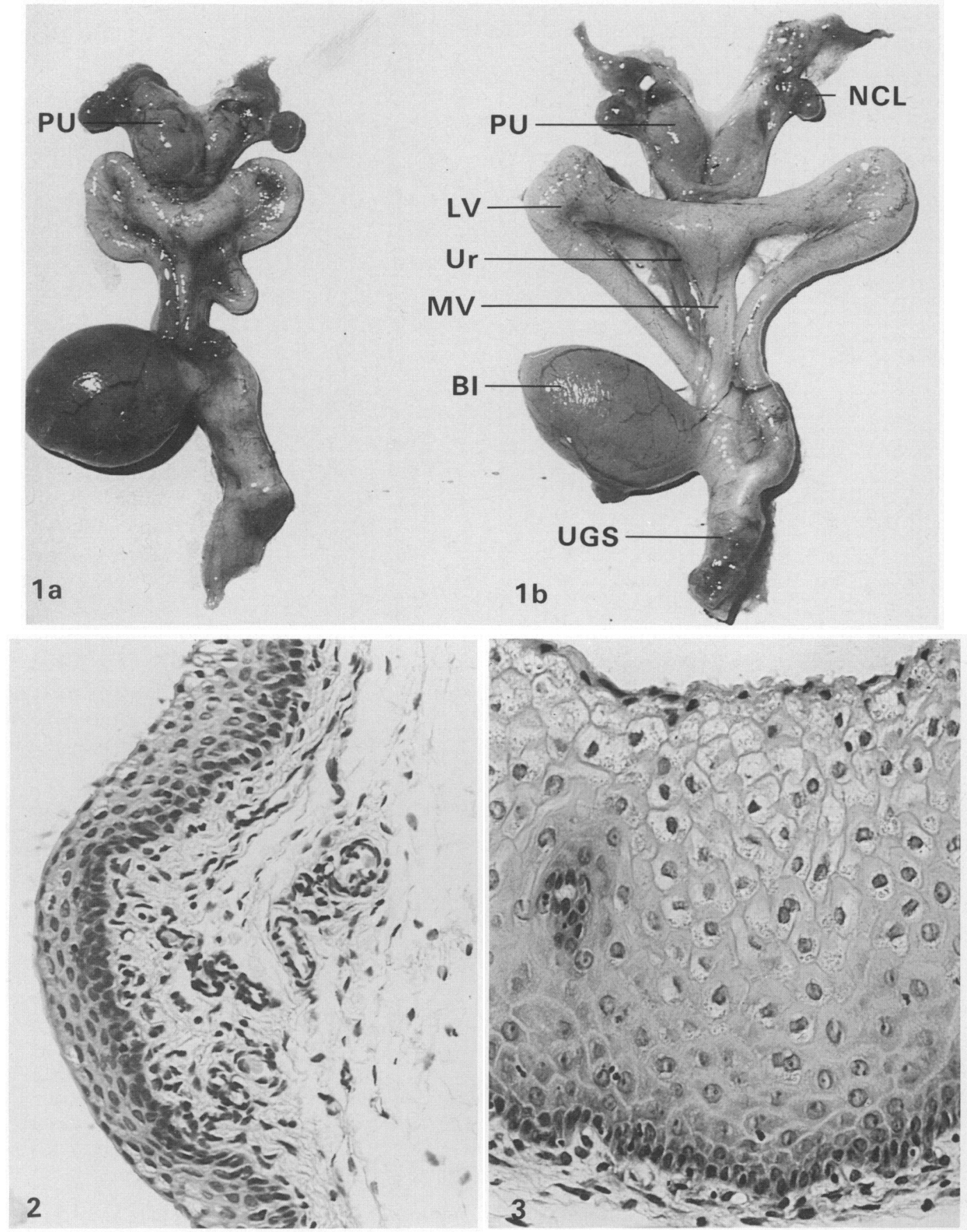
PLATE 2
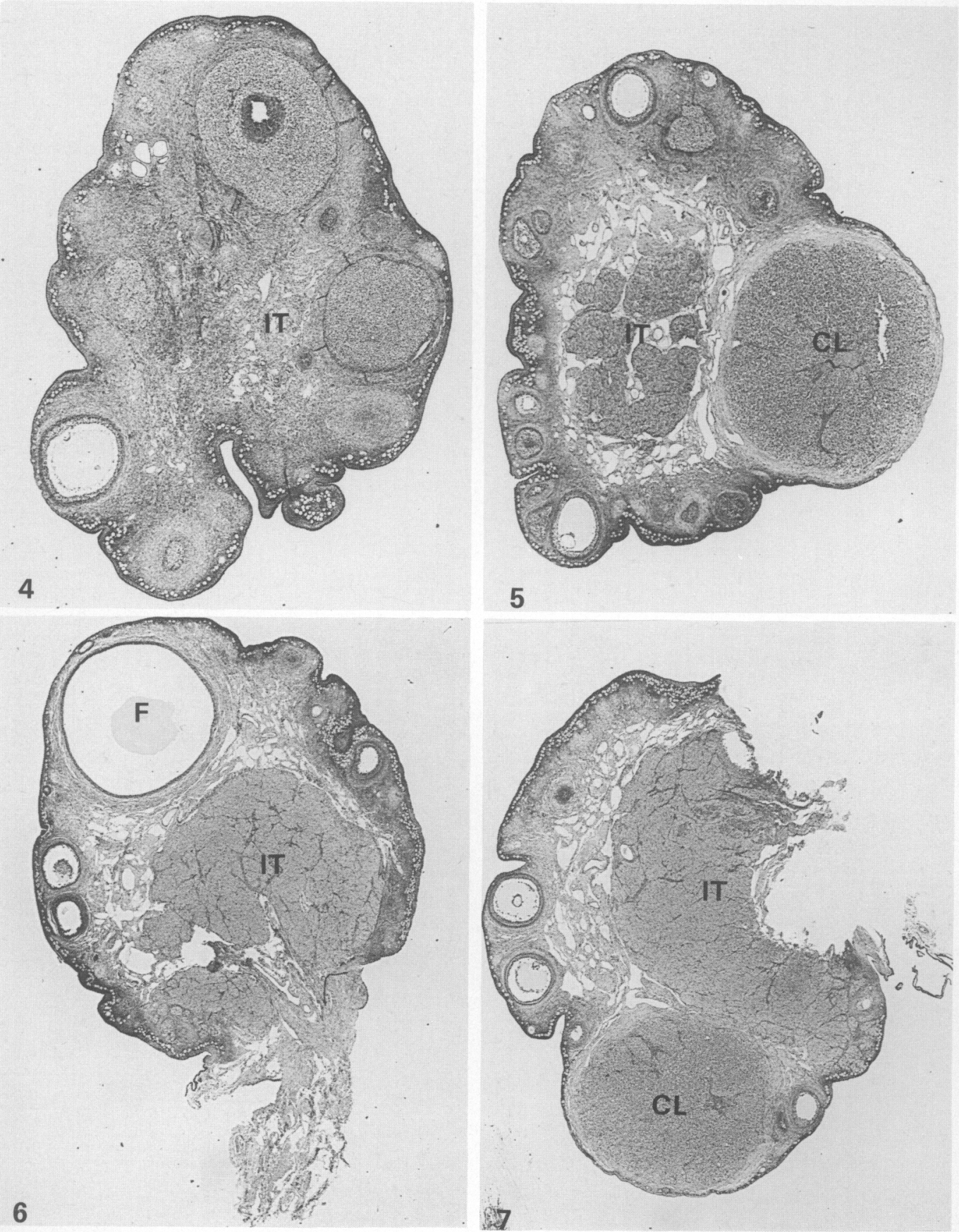


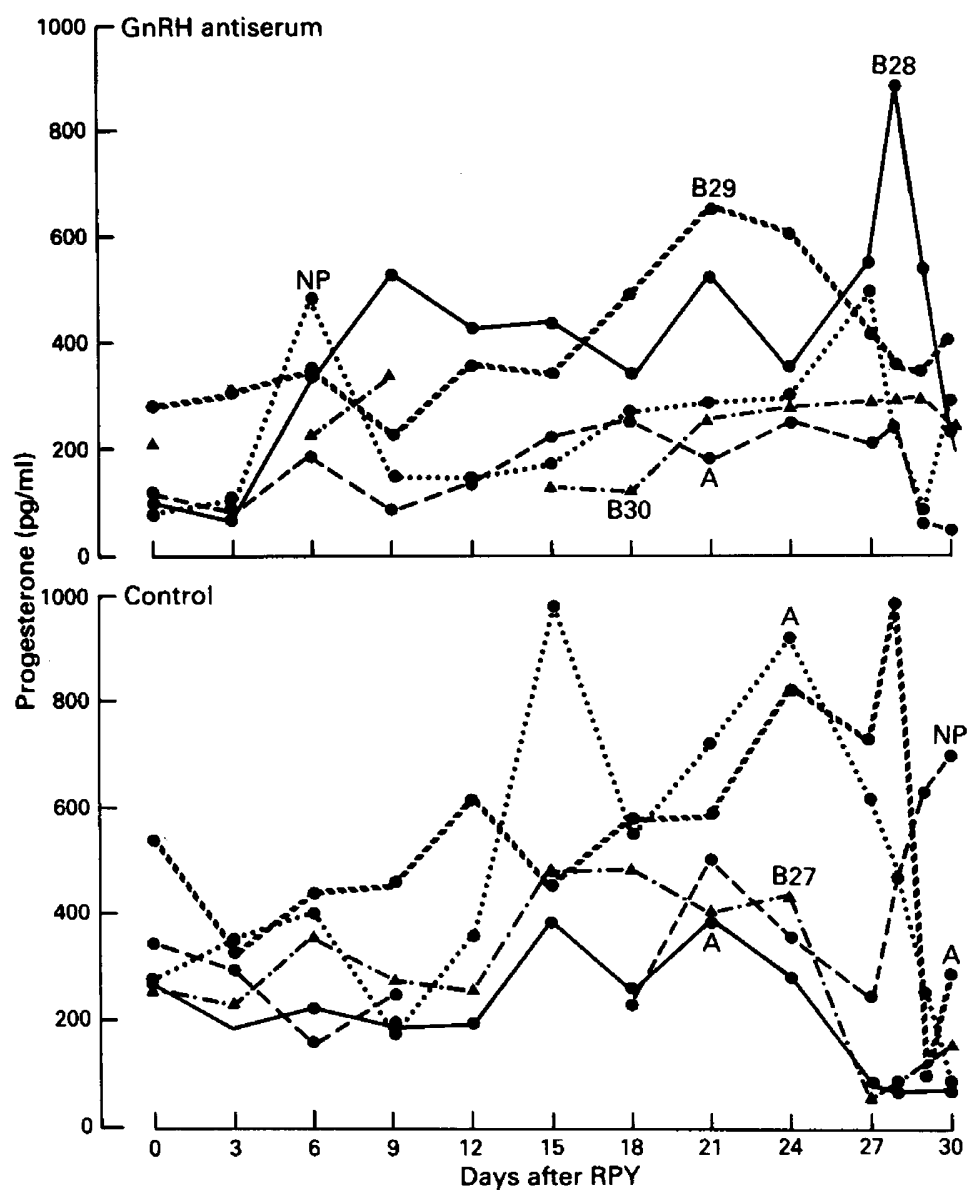

Text-fig. 2. Plasma progesterone concentrations throughout pregnancy for individual treated and control animals. $\mathrm{A}=$ aborted; $\mathrm{B}=$ gave birth on day indicated by numbers; $\mathrm{NP}=$ not pregnant.

\section{PLATE 2}

Fig. 4. Left ovary of a GnRH-immunized animal, No. 1186, showing absence of any large preovulatory follicles. IT, interstitial tissue. $\times 13$.

Fig. 5. Right ovary of a GnRH-immunized animal, No. 1186, showing regressing corpus luteum of the previous cycle. IT, interstitial tissue; CL, corpus luteum. $\times 10$.

Fig. 6. Left ovary of a control animal, No. 1173, which had just mated, showing a large unruptured preovulatory follicle. IT, interstitial tissue; F, follicle. $\times 9$.

Fig. 7. Right ovary of a control animal, No. 1173, showing regressing corpus luteum of the previous cycle. IT, interstitial tissue; $\mathrm{CL}$, corpus luteum. $\times 10$. 
time of parturition. There was no difference between the treated and control groups, confirming the morphological evidence that antiserum administration had no inhibitory effect on luteal activity. The oestrogen concentrations (mean \pm s.e.m.) did not differ between the treated and control groups at any stage (controls, $8.1 \pm 0.8-14.2 \pm 1.2 \mathrm{pg} / \mathrm{ml}$; treated, $8.1 \pm 1.4$ $14.2 \pm 1.7 \mathrm{pg} / \mathrm{ml}$ ), and were similar to previously reported basal values found throughout gestation (Flint \& Renfree, 1982; Shaw \& Renfree, 1984).

\section{Discussion}

In passive immunization experiments with hormone antibodies, it is always difficult to determine how completely the hormone in question has been neutralized. This is especially true in animals immunized against GnRH, in which the hormone and the antibody can have only a few seconds to interact in the portal circulation before the GnRH reaches its receptors in the pituitary. Nevertheless, the evidence is that acute passive immunization of rats and hamsters in pro-oestrus with GnRH antibodies will inhibit the preovulatory surge of LH and FSH and hence prevent ovulation, whilst passive immunization of rams produces an instantaneous cessation of all episodic pituitary LH secretion, and hence an immediate decline in testicular testosterone production (Fraser, 1981). It is unlikely that pituitary gonadotrophin secretion was completely abolished in the present experiments, because even the actively immunized males that had GnRH antibody titres of 1:4800 and 1:6400 after 6 months still showed histological evidence of spermatogenesis, although the testes had shrunk to about two thirds of their normal size. Repeated passive immunizations of the females with $8 \mathrm{ml}$ of an antiserum having a titre of 1:12 000 only achieved antibody titres of up to 1:850, and, in the absence of sufficiently sensitive assays for wallaby gonadotrophins, we were unable to quantify the degree of gonadotrophin inhibition.

Nevertheless, there can be no doubt from the absence of copulatory plugs, the lack of large ovarian follicles at laparotomy on Day 24 , the absence of preovulatory follicles or new corpora lutea at autopsy on Day 30, and the absence of an oestrogenic response in the vagina, that the GnRH antiserum did inhibit follicular development during late gestation, and prevent post-partum oestrus and ovulation. The fact that this in no way interfered with pregnancy or parturition is strong evidence to suggest that rising follicular oestrogen secretion in late gestation is not involved in the initiation of parturition, a finding that is in accord with the observations of Harder et al. (1985), who surgically removed the ovary containing the large preovulatory follicle in late gestation and showed that it did not affect the time of birth.

Inhibition of gonadotrophin secretion did not prevent normal luteal reactivation or progesterone secretion after removal of the pouch young. This agrees with the results of Hearn (1974), who showed that complete hypophysectomy also produced luteal reactivation if performed during embryonic diapause, suggesting that the corpus luteum at this stage is independent of gor adotrophin secretion.

Parturition fails to occur in tammars after hypophysectomy (Hearn, 1974), and, depending on the time of surgery, it is inhibited by removal of the CL or the ovaries (Young \& Renfree, 1979; Harder et al., 1985). It appears that a functional corpus luteum is a necessary prerequisite for normal parturition, and that the pre-partum decline in luteal progesterone secretion may be caused by a transitory rise in prolactin secretion which occurs in pregnant animals at this time (Tyndale-Biscoe, Hinds, Horn \& Jenkin, 1983; Stewart \& Tyndale-Biscoe, 1983). The fact that neither luteal regression nor parturition was affected by GnRH immunization is in accord with these observations, and we çonclude that the tammar's corpus luteum must receive adequate gonadotrophic support for its normal 1 year lifespan at the time of ovulation; any subsequent modulation of luteal activity must be produced by changes in pituitary inhibitory activity.

Lactogenesis, as measured by an increase in mammary gland lactose concentrations, was established in all animals. It is known that lactose concentrations are highest on the day of birth in 
sucked and non-sucked glands (Findlay et al., 1983). The fact that lactose concentrations were higher in the immunized than in the control group in our study is probably a reflection of the fact that the treated animals tended to give birth closer to the day of autopsy than the controls, as judged by the drop in plasma progesterone concentrations, and we would be reluctant to ascribe any physiological significance to this apparent difference.

At no stage could we detect a difference in oestrogen concentrations between the plasma of control and treated animals. The fact that we were unable to detect a significant preovulatory oestrogen rise even in the controls that came into oestrus and ovulated normally confirms that once-daily blood sampling is too infrequent to monitor this event successfully, as shown by Shaw $\&$ Renfree (1984) and Harder et al. (1985). The oestradiol peak occurs just after birth, $8 \mathrm{~h}$ after the fall in progesterone, and concentrations remain elevated for less than $24 \mathrm{~h}$, falling to basal values $12 \mathrm{~h}$ before ovulation. As progesterone had fallen in most of the control animals by Day 25, a peak of oestrogen $8 \mathrm{~h}$ later would certainly have been missed by sampling only on Days 24 and 27 .

We conclude that changes in pituitary FSH and LH secretion are not required in the tammar for luteal reactivation, pregnancy, parturition and lactogenesis, but that they are essential for follicular development during gestation and post-partum oestrus and ovulation.

We thank Dr H. M. Fraser for advice about active immunization, and for measuring the GnRH antibody titres; Dr D. W. Lincoln and Dr E. J. Thornber for help with the active immunizations; Dr L. Findlay and Ms K. Ward for the lactose concentration measurements; and Mr S. Green for all the progesterone assays. This study was supported by grants to M.B.R. from the Australian Research Grants Scheme (D1-75/13759) and the National Institutes of Health, U.S.A. (HD-09387).

\section{References}

Findlay, L., Ward, K.L. \& Renfree, M.B. (1983) Mammary gland lactose, plasma progesterone and lactogenesis in the marsupial, Macropus eugenii. J. Endocr. 97, 425-436.

Flint, A.P.F. \& Renfree, M.B. (1982) Oestradiol-17 $\beta$ in the blood during seasonal reactivation of the diapausing blastocyst in a wild population of tammar wallabies. J. Endocr. 85, 293-300.

Fraser, H.M. (1981) Luteinising hormone-releasing hormone and fertility control. Oxford Rev. Reprod. Biol. $3,1-48$.

Harder, J.D., Hinds, L.A., Horn, C.A. \& Tyndale-Biscoe, C.H. (1984) Oestradiol in follicular fluid and in utero-ovarian venous and peripheral plasma during parturition and post-partum oestrus in the tammar, Macropus eugenii. J. Reprod. Fert. 72, 551-558.

Harder, J.D., Hinds, L.A., Horn, C.A. \& Tyndale-Biscoe, C.H. (1985) Effects of removal in late pregnancy of the corpus luteum, Graafian follicle or ovaries on plasma progesterone, oestradiol, LH, parturition and post partum oestrus in the tammar wallaby, Macropus eugenii. J. Reprod. Fert. 75, 449-459.

Hearn, J.P. (1974) The pituitary gland and implantation in the tammar wallaby, Macropus eugenii. J. Reprod. Fert. 39, 235-241.

Renfree, M.B., Green, S.W. \& Young, I.R. (1979) Growth of the corpus luteum and its progesterone content during pregnancy in the tammar wallaby, Macropus eugenii. J. Reprod. Fert. 57, 131-136.
Shaw, G. \& Renfree, M.B. (1984) Concentrations of oestradiol-17 $\beta$ in plasma and corpora lutea throughout pregnancy in the tammar, Macropus eugenii. J. Reprod. Fert. 72, 29-37.

Stewart, F. \& Tyndale-Biscoe, C.H. (1983) Pregnancy and parturition in marsupials. In Current Topics in Experimental Endocrinology, Vol. 4, pp. 1-33. Eds L. Martini \& V.H.T. James. Academic Press, London.

Tyndale-Biscoe, C.H. (1984) Mammals: Marsupials. In Marshall's Physiology of Reproduction, 4th edn, Vol. 1, Ch. 6, pp. 386-454. Ed. G. E. Lamming. ChurchillLivingstone, Edinburgh.

Tyndale-Biscoe, C.H. \& Renfree, M.B. (1986) Marsupial Reproduction. Cambridge University Press.

Tyndale-Biscoe, C.H., Hearn, J.P. \& Renfree, M.B. (1974) Control of reproduction in macropodid marsupials. J. Endocr. 63, 589-614.

Tyndale-Biscoe, C.H., Hinds, L.A., Horn, C.A. \& Jenkin, G. (1983) Hormonal changes at oestrus, parturition and post-partum oestrus in the tammar wallaby (Macropus eugenii). J. Endocr. 96, 155-161.

Ward, K.L. \& Renfree, M.B. (1984) Effects of progesterone on parturition in the tammar, Macropus eugenii. J. Reprod. Fert. 72, 21-28.

Young, I.R. \& Renfree, M.B. (1979) The effects of corpus luteum removal during gestation on parturition in the tammar wallaby (Macropus eugenii). J. Reprod. Fert. 56, 249-254.

Received 3 April 1985 